\section{OPTIMALISASI PENGELOLAAN RUSUNAWA DI KOTA SEMARANG}

\author{
Boy Pardamean Mahulae, S Sunarti* \\ Departemen Perencanaan Wilayah dan Kota, Fakultas Teknik, \\ Universitas Diponegoro, Semarang, Indonesia
}

Jurnal Pengembangan Kota (2021) Volume 9 No. $2(245-258)$ Tersedia online di:

http://ejournal2.undip.ac.id/index.php/jpk DOI: 10.14710/jpk.9.2.245-258

\begin{abstract}
Abstrak. Rusunawa merupakah salah satu program untuk mengatasi permasalahan keterbatasan lahan dan ketidakmampuan MBR untuk menjangkau fasilitas hunian. Seiring dengan pembangunan rusunawa saat ini, terdapat beberapa permasalahan pasca pembangunan, salah satunya tentang pengelolaannya. Pengelolaan rusunawa di Kota Semarang secara umum sudah tidak sesuai lagi dengan tujuan penyediaan rusunawa, yaitu memberikan hunian yang layak, sehat, dan terjangkau untuk MBR. Ketidaksesuaian tersebut antara lain kondisi bangunan mulai rusak, kualitas lingkungan menurun dan terdapat pelanggaran terhadap sistem sewa maupun pemanfaatan bangunan. Salah satu faktor terjadinya permasalahan ketidaksesuaian tersebut yaitu belum optimalnya pengelola dalam menjalankan peran dan fungsinya. Oleh karena itu, tujuan penelitian ini adalah untuk menganalisis optimalisasi pengelolaan rusunawa di Kota Semarang. Metode penelitian yang digunakan adalah metode kuantitatif dengan menggunakan analisis skoring pembobotan. Responden pada penelitian ini berjumlah 28 yang merupakan ketua paguyuban pengelola rusunawa di Kota Semarang. Hasil penelitian menunjukkan bahwa pengelolaan rusunawa di Kota Semarang masih belum optimal berdasarkan peran dan fungsi masing-masing pengelola. Skor optimalisasi yang diperoleh yaitu Paguyuban $(7,7)$, Disperkim $(7,4)$, dan UPTD $(6,4)$. Oleh karena itu, diperlukan peningkatan pengelolaan terhadap penghuni dan hunian rusunawa seperti (1) pemeliharaan dan perbaikan fasilitas, monitoring dan evaluasi target capaian pengelolaan, serta pembinaan dan pengawasan terkait kebersihan lingkungan oleh Disperkim; (2) Melakukan pembinaan terhadap penghuni dan hunian, menjalankan prosedur pengelolaan dan monitoring untuk mengurangi pelanggaran tata tertib oleh UPTD; (3) Melakukan pengorganisasian paguyuban dalam pengoperasionalan rusunawa agar memudahkan koordinasi antarpihak dalam mengatasi permasalahan dan meningkatkan kualitas rusunawa.
\end{abstract}

Kata kunci : Optimal; Pengelolaan; Rusunawa

[Title: Optimalisation Rental Flats Management of Semarang City]. Rental Flat is a program to overcome the problem of limited land and the inability of MBR to reach residential facilities. The development of Rental Flats has several postdevelopment problems, one of which is related to its management. The management of Rusunawa in Semarang City, in general, is no longer the purpose of providing Rusunawa, which is to provide decent, healthy, and affordable housing for $M B R$. These problems include the condition of damaged buildings, declining environmental quality, and violations of the rental system and building utilization. One of the factors causing these problems is that stakeholders are not optimal in carrying out their roles and functions. Therefore, the purpose of this study was to analyze the optimization of the management of flats in the city of Semarang. The research method used is a quantitative method using a weighting scoring analysis. Respondents in this study found 28 who were the heads of the association of Rental Flats managers in Semarang City. The results showed that the management of Rental Flats in the city of Semarang is still not optimal. The optimal assessment of whether or not the management of the Rental Flats is based on the roles and functions of each stakeholder. The optimization scores obtained were Paguyuban (7.7), Disperkim (7.4), and UPTD (6.4). Therefore, it is necessary to improve the management of rental flats residents and dwellings, such as (1) maintenance and repair of facilities, monitoring and evaluation of management achievement targets, as well as guidance and supervision related to environmental cleanliness by Disperkim; (2) Provide guidance to residents and dwellings, carry out management and monitoring procedures to reduce violations of the rules by the UPTD; (3) Organizing the association in the operation of the Rusunawa to facilitate coordination between parties in overcoming problems and improving the quality of the rental flats.

Keyword: Optimal; Management; Rental Flats

Cara Mengutip: Mahulae, Boy Pardamean., \& Sunarti, S. (2021). Optimalisasi Pengelolaan Rusunawa di Kota Semarang. Jurnal Pengembangan Kota. Vol 9 (2): 245-258. DOI: 10.14710/jpk.9.2.245-258 


\section{PENDAHULUAN}

Pertumbuhan penduduk yang terus meningkat menyebabkan kebutuhan hunian juga semakin meningkat setiap tahunnya. Hal ini mengakibatkan zona perkotaan tumbuh secara tidak teratur dan horizontal, sehingga menimbulkan sebuah kota yang tersebar eksklusif dan inefisiensi (Vásquez dkk., 2014). Sementara itu, dari sisi penyediaan jumlah fasilitas hunian belum mampu memenuhi penyediaan hunian bagi masyarakat, sehingga menimbulkan backlog. Backlog adalah kuantitas rumah yang belum tertangani (South Hampshire Housing Market Assessment, 2005). Backlog terjadi karena meningkatnya jumlah populasi luar biasa namun tidak diimbangi dengan jumlah unit hunian yang mengakibatkan kepadatan penduduk tinggi, tingkat hunian yang rendah, kondisi penduduk kota yang buruk, dan rendahnya layanan infrastruktur dan tingginya tingkat kejahatan (Ugochukwu \& Chioma, 2015).

Dalam menyelesaikan permasalahan hunian di perkotaan, pemerintah berupaya mengatasi permasalahan hunian tersebut dengan pembangunan fasilitas hunian. Kendala yang dihadapi dalam mewujudkan pembangunan fasilitas hunian yaitu terbatasnya ketersediaan lahan di perkotaan dan keterbatasan kemampuan masyarakat berpenghasilan rendah (MBR) untuk menjangkau landed house, sehingga salah satu program yang dianggap mampu mengatasi permasalahan keterbatasan lahan dan kemampuan MBR untuk menjangkau fasilitas hunian yaitu melalui program rumah susun sederhana sewa (rusunawa) (Permatasari, 2012).

Seiring dengan pembangunan rusunawa saat ini, terdapat beberapa permasalahan pasca pembangunan, salah satunya tentang pengelolaannya. Salah satu kota di Indonesia yang memiliki masalah pengelolaan rusunawa adalah Kota Semarang. Kota Semarang memiliki 7 (tujuh) rusunawa, yaitu: Rusunawa Pekunden, Rusunawa Bandarharjo, Rusunawa Karangroto, Rusunawa Plamongansari, Rusunawa Kaligawe, Rusunawa Kudu dan Rusunawa Jrakah. Saat ini, permasalahan yang kerap terjadi pada rusunawa di Kota Semarang secara umum sudah tidak sesuai lagi dengan tujuan penyediaan rusunawa, yaitu memberikan hunian yang layak, sehat, dan terjangkau untuk MBR. Ketidaksesuaian itu antara lain kondisi bangunan mulai rusak, kualitas lingkungan menurun, dan penghunian tidak tertib seperti terjadi alih huni di bawah tangan, memperjual belikan hunian, status hunian sewa tidak jelas lagi, pelanggaran terhadap pemanfaatan bangunan dan bagian bersama, perawatan bangunan hampir tidak ada, serta pelayanan prasarana umum yang kurang berfungsi (Hendaryono, 2010).

Permasalahan-permasalahan tersebut diakibatkan karena masing-masing pengelola rusunawa masih belum optimal dalam menjalankan peran dan fungsinya, baik dalam pengelolaan proses penghunian maupun pengelolaan fisik bangunan dan PSU (prasarana, sarana, dan utilitas umum) rusunawa. Lemahnya tahap controlling yang dilakukan oleh pihak pemerintah dan kinerja kelembagaan pemerintah daerah dinilai sangat rendah (Hendaryono, 2010). Pengelolaan Rusunawa di Kota Semarang saat ini diselenggarakan oleh Dinas Perumahan dan Kawasan Permukiman (Disperkim), Unit Pelaksana Teknis Daerah (UPTD) Rusunawa Kota Semarang dan paguyuban pengelola masing-masing rusunawa. Permasalahan pengelolaan ini dalam kurun waktu tertentu, jika tidak segera tertangani dapat menimbulkan berbagai permasalahan yang berdampak terhadap kelayakan hunian rusunawa (Sitepu, 2006).

Penelitian tentang pengelolaan rusunawa telah banyak dilakukan oleh peneliti sebelumnya (Ardiyanti \& Rahaju, 2019; Astuti, 2021; Purnamasari dkk., 2020; Sari dkk., 2016; Soukotta dkk., 2013; Subkhan, 2008). Namun, penelitian terkait penilaian optimalisasi pengelolaan di beberapa rusunawa khususnya rusunawa di Kota Semarang belum pernah dilakukan. Berdasarkan gap penelitian yang belum pernah dilakukan tersebut, maka penelitian ini bertujuan untuk menganalisis optimalisasi pengelolaan rusunawa di Kota Semarang.

\section{METODE PENELITIAN}

Metode penelitian yang digunakan yaitu metode penelitian kuantitatif. Metode penelitian kuantitatif

\section{ISSN 2337-7062 (C) 2021}

This is an open access article under the CC-BY-NC-ND license (http://creativecommons.org/licenses/by-nc-sa/4.0/). - lihat halaman depan (C) 2021

*Email sunarti@pwk.undip.ac.id

Diterima 17 Juni 2021, disetujui 30 November 2021 
digunakan karena dapat mengkonstruksikan hubungan antar fenomena dengan menggunakan statistik untuk mengetahui hubungan antar fenomena (Sugiyono, 2017). Metode penelitian kuantitatif digunakan untuk melakukan penilaian optimasi pengelolaan rusunawa di Kota Semarang.

Komponen penilaian dikategorikan menjadi 3 (tiga) nilai, yaitu 1 (tidak optimal), 2 (kurang optimal) dan 3 (optimal). Pengelolaan rusunawa dapat dikategorikan optimal apabila komponen peran dan fungsi masing-masing pengelola rusunawa dapat dilaksanakan sesuai dengan ketentuan yang berlaku dengan ambang batas skor 8-10, sedangkan pengelolaan yang dikategorikan kurang optimal apabila hanya dapat memenuhi sebagian komponen dengan ambang batas skor 5-7,9 dan pengelolaan yang dikategorikan tidak optimal apabila hanya memenuhi sebagian kecil komponen pengelolaan dengan ambang batas 1-4,9. Ambang batas ini merujuk pada penelitian (Subkhan, 2008). Menurut Subkhan (2008), pengelolaan rusunawa dikategorikan optimal jika terpenuhinya seluruh komponen pengelolaan meliputi (1) komponen operasional pengelolaan teknis prasarana dan sarana, (2) pengelolaan persewaan, pemasaran dan pembinaan penghuni, (3) pengelolaan administrasi dan keuangan, dengan ambang batas skor 8-10. Sedangkan kurang optimal jika hanya dapat memenuhi sebagian komponen optimal dengan ambang batas $5-7,9$, serta pengelolaan yang tidak optimal jika hanya sebagian kecil yang dapat terpenuhi dari beberapa komponen pengelolaan optimal dengan ambang batas skor 1-4,9. Oleh karena itu, penelitian ini dapat diklasifikasikan ke dalam 3 (tiga) penilaian, yaitu skor 8-10 (optimal), 57,9 (kurang optimal) serta 1-4,9 (tidak optimal) sesuai dengan penilaian terhadap komponen peran dan fungsi masing-masing pengelola setiap rusunawa di Kota Semarang.

Lokasi penelitian yaitu di 7 rusunawa Kota Semarang yang dikelola oleh Dinas Perumahan dan Kawasan Permukiman serta UPTD Rusunawa Kota Semarang yaitu: Rusunawa Bandarharjo, Rusunawa Pekunden, Rusunawa Karangroto, Rusunawa Plamongansari, Rusunawa Kaligawe, Rusunawa Kudu dan Rusunawa Jrakah dengan persebaran lokasi seperti pada Gambar 1.

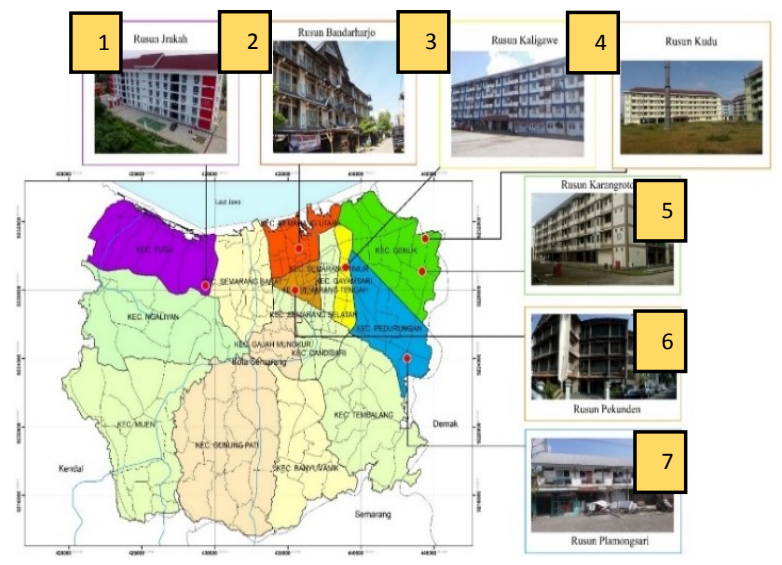

Gambar 1. Peta Persebaran Rusunawa di Kota Semarang Keterangan :

1. Rusunawa Jrakah terletak di Kelurahan Jrakah, Kecamatan Tugu.

2. Rusunawa Bandarharjo terletak di Kelurahan Bandarharjo, Kecamatan Semarang Utara

3. Rusunawa Kaligawe terletak di Kelurahan Kaligawe, Kecamatan Gayamsari

4. Rusunawa Kudu terletak di Kelurahan Kudu, Kecamatan Genuk

5. Rusunawa Karangroto terletak di Kelurahan Karangroto, Kecamatan Genuk

6. Rusunawa Pekunden terletak di Kelurahan Pekunden, Kecamatan Semarang Tengah

7. Rusunawa Plamongansari terletak di Kelurahan Plamongansari, Kecamatan Pedurungan

Teknik analisis yang digunakan adalah teknik analisis skoring pembobotan. Metode pengumpulan data yang digunakan adalah teknik pengumpulan data primer dan sekunder. Data primer diperoleh melalui kuesioner, wawancara dan observasi, sedangkan data sekunder diperoleh melalui telaah dokumen. Jumlah responden dalam penelitian ini yaitu 28 responden yang merupakan ketua paguyuban pengelola rusunawa di Kota Semarang. Wawancara dilakukan dengan instansi terkait yaitu Dinas Perumahan dan Kawasan Permukiman Kota Semarang, pihak UPTD Rumah Susun Kota Semarang dan organisasi pengelola yang ada di setiap rusunawa di Kota Semarang sebagai pendukung hasil kuesioner yang telah dilakukan.

\section{HASIL DAN PEMBAHASAN}

Pengelola rusunawa terdiri dari Dinas Perumahan dan Kawasan Permukiman, UPTD Rumah Susun dan paguyuban pengelola rusunawa di Kota Semarang. Tabel 1 merupakan peran dan fungsi masing-masing pengelola rusunawa Kota Semarang. 
Tabel 1. Peran dan Fungsi Pengelola Rusunawa Kota Semarang

\begin{tabular}{|c|c|c|}
\hline $\begin{array}{c}\text { Pihak } \\
\text { Disperkim }\end{array}$ & Pihak UPTD & $\begin{array}{c}\text { Pihak } \\
\text { Paguyuban }\end{array}$ \\
\hline $\begin{array}{l}\text { Pemeliharaan } \\
\text { rusunawa berupa } \\
\text { perawatan dan } \\
\text { perbaikan fisik } \\
\text { bangunan dan } \\
\text { PSU rusunawa }\end{array}$ & $\begin{array}{l}\text { Pengelolaan } \\
\text { proses } \\
\text { penghunian } \\
\text { seperti } \\
\text { pelaksanaan } \\
\text { prosedur- } \\
\text { prosedur } \\
\text { penghunian }\end{array}$ & $\begin{array}{l}\text { Mengkoordinir } \\
\text { pengelolaan } \\
\text { masing-masing } \\
\text { rusunawa baik } \\
\text { penghunian } \\
\text { maupun } \\
\text { pemeliharaan } \\
\text { rusunawa }\end{array}$ \\
\hline $\begin{array}{l}\text { Pembiyaan } \\
\text { rusunawa terkait } \\
\text { pemeliharaan } \\
\text { rusunawa }\end{array}$ & $\begin{array}{l}\text { Tepat sasaran } \\
\text { penghuni } \\
\text { rusunawa }\end{array}$ & $\begin{array}{l}\text { Pengorganisasian } \\
\text { pihak paguyuban } \\
\text { rusunawa }\end{array}$ \\
\hline $\begin{array}{l}\text { Pembinaan } \\
\text { penghuni terkait } \\
\text { pemeliharaan fisik } \\
\text { rusunawa }\end{array}$ & $\begin{array}{l}\text { Sistem sewa } \\
\text { menyewa } \\
\text { peghuni } \\
\text { rusunawa }\end{array}$ & \multirow{4}{*}{$\begin{array}{l}\text { Pelaksanaan } \\
\text { pemeliharaan } \\
\text { rusunawa baik } \\
\text { fisik bangunan } \\
\text { dan PSU } \\
\text { rusunawa oleh } \\
\text { pihak paguyuban }\end{array}$} \\
\hline \multirow[t]{3}{*}{$\begin{array}{l}\text { Monitoring dan } \\
\text { evaluasi oleh } \\
\text { pihak Disperkim }\end{array}$} & $\begin{array}{l}\text { Pengorganisasian } \\
\text { pihak UPTD } \\
\text { terkait } \\
\text { pengelolaan } \\
\text { rusunawa }\end{array}$ & \\
\hline & $\begin{array}{l}\text { Pembinaan } \\
\text { penghuni terkait } \\
\text { proses } \\
\text { penghunian }\end{array}$ & \\
\hline & $\begin{array}{l}\text { Kegiatan } \\
\text { Monitoring dan } \\
\text { evaluasi oleh } \\
\text { Pihak UPTD }\end{array}$ & \\
\hline
\end{tabular}

Berdasarkan Tabel 1 peran dan fungsi dari ketiga pengelola rusunawa tersebut dilakukan analisis peran dan fungsi dari masing-masing pengelola melalui skoring pembobotan yang telah dijeskan pada sub bab metode yaitu dengan penilaian optimal dengan ambang batas skor 8-10, kurang optimal dengan ambang batas skor 5-7,9 dan tidak optimal dengan ambang batas 1-4,9.

\section{A. Analisis Peran dan Fungsi Disperkim Kota Semarang}

1. Analisis Pemeliharaan dan Perawatan Rusunawa oleh Disperkim

Disperkim berperan dalam pelaksanaan pemeliharaan, peningkatan dan pembangunan fisik bangunan rusunawa berupa sarana dan prasarana. Pemeliharaan rusunawa sangat penting dilakukan untuk memperpanjang usia bangunan, untuk menjamin ketersediaan perlengkapan yang ada dan juga mendapatkan keuntungan dari investasi yang maksimal, untuk menjamin keselamatan manusia yang menggunakan bangunan tersebut, untuk menjamin kesiapan operasional dari setiap peralatan atau perlengkapan dalam menghadapi situasi darurat seperti kebakaran, seta menekan tingginya biaya perwatan dengan melakukan kegiatan perawatan secara efektif dan efisien (Assauri, 2008).

Kegiatan pemeliharaan dapat dibedakan menjadi dua jenis, yaitu pemeliharaan pencegahan (preventive maintenance) dan pemeliharaan perbaikan (corrective maintenance). Pemeliharaan pencegahan menurut O'Connor (2001) adalah kegiatan yang mencegah untuk timbulnya kerusakan-kerusakan bangunan gedung serta fasilitas yang tidak terduga dan menemukan kondisi atau keadaan yang dapat menyebabkan terjadinya kerusakan. Sedangkan pemeliharaan perbaikan adalah kegiatan perawatan yang dilakukan pada fasilitas gedung yang tidak dapat berfungsi dengan baik atau mengalami kerusakan, sehingga diperlukan tindakan perbaikan O'Connor (2001).

Kegiatan pemeliharaan rusunawa Kota Semarang adalah kegiatan pemeliharaan perbaikan (corrective maintenance). Hal ini dikarenakan, kegiatan pemeliharaan yang dilakukan oleh pihak Disperkim hanya dilakukan apabila terjadi kerusakan pada fasilitas hunian rusunawa, sedangkan untuk kegiatan pemeliharaan pencegahan tidak sepenuhnya dilakukan. Tabel 2 merupakan hasil kuesioner terkait intensitas kegiatan pemeliharaan berupa perawatan dan perbaikan gedung dan PSU rusunawa yang dilakukan oleh Disperkim.

Tabel 2. Intensitas Perawatan dan Perbaikan

Rusunawa oleh Disperkim Kota Semarang

\begin{tabular}{|l|c|c|c|c|}
\hline $\begin{array}{c}\text { Intensitas } \\
\text { Perawatan } \\
\text { dan } \\
\begin{array}{l}\text { Rerbaikan } \\
\text { oleh Pihak } \\
\text { Disperkim }\end{array}\end{array}$ & $\begin{array}{c}\text { Rutin } \\
\text { dilaku } \\
\text { kan } \\
\text { setiap } \\
\text { tahun }\end{array}$ & $\begin{array}{c}\text { Tidak } \\
\text { menentu, } \\
\text { tergantung } \\
\text { kerusakan }\end{array}$ & $\begin{array}{c}\text { Jarang } \\
\text { dilakukan }\end{array}$ & $\begin{array}{c}\text { Tidak } \\
\text { pernah }\end{array}$ \\
\hline $\begin{array}{l}\text { Rusunawa } \\
\text { Pekunden }\end{array}$ & 0 & 1 & 0 & 0 \\
\hline $\begin{array}{l}\text { Rusunawa } \\
\text { Bandarharjo }\end{array}$ & 0 & 3 & 0 & 0 \\
\hline $\begin{array}{l}\text { Rusunawa } \\
\text { Plamongan- } \\
\text { sari }\end{array}$ & 0 & 6 & 0 & 0 \\
\hline $\begin{array}{l}\text { Rusunawa } \\
\text { Karangroto }\end{array}$ & 0 & 3 & 1 & 0 \\
\hline $\begin{array}{l}\text { Rusunawa } \\
\text { Kaligawe }\end{array}$ & 0 & 6 & 0 & 0 \\
\hline
\end{tabular}




\begin{tabular}{|l|c|c|c|c|}
\hline $\begin{array}{c}\text { Intensitas } \\
\text { Perawatan } \\
\text { dan } \\
\begin{array}{c}\text { Perbaikan } \\
\text { Rusunawa } \\
\text { oleh Pihak } \\
\text { Disperkim }\end{array}\end{array}$ & $\begin{array}{c}\text { Rutin } \\
\text { dilaku } \\
\text { kan } \\
\text { setiap } \\
\text { tahun }\end{array}$ & $\begin{array}{c}\text { Tidak } \\
\text { menentu, } \\
\text { tergantung } \\
\text { kerusakan }\end{array}$ & $\begin{array}{c}\text { Jarang } \\
\text { dilakukan }\end{array}$ & $\begin{array}{c}\text { Tidak } \\
\text { pernah }\end{array}$ \\
\hline $\begin{array}{l}\text { Rusunawa } \\
\text { Kudu }\end{array}$ & 1 & 6 & 0 & 0 \\
\hline $\begin{array}{l}\text { Rusunawa } \\
\text { Jrakah }\end{array}$ & 1 & 0 & 0 & 0 \\
\hline Jumlah & 2 & 25 & 1 & 0 \\
\hline Persentase & $\mathbf{7 \%}$ & $\mathbf{8 9 \%}$ & $\mathbf{4 \%}$ & $\mathbf{0 \%}$ \\
\hline
\end{tabular}

Dari data pada Tabel 2, dapat dilihat bahwa intensitas kegiatan perbaikan dan pemeliharaan rusunawa yang dilakukan oleh pihak Disperkim masih kurang. Berdasarkan hasil kuesioner kepada responden paguyuban, pihak Disperkim melakukan kegiatan pemeliharaan hampir di semua rusunawa hanya pada saat terjadi kerusakan (89\%), sedangkan untuk kegiatan pemeliharaan secara rutin dilakukan hanya di Rusunawa Jrakah (4\%).

Di dalam Peraturan Menteri Perumahan Rakyat No.14 Tahun 2007 Tentang Pengelolaan Rumah Susun Sederhana Sewa, kegiatan pemeliharaan fasilitas rusunawa dikategorikan menjadi 4 kegiatan, yaitu: perawatan rutin, perawatan berkala, perawatan mendesak, dan perawatan darurat. Kegiatan perawatan rutin berupa kegiatan pengoperasian, perbaikan kecil peralatan utilitas dan keamanan bangunan. Kegiatan perawatan berkala merupakan kegiatan yang direncanakan menurut jangka waktu dan diatur menurut jadwal tertentu dengan tujuan mencegah kerusakan.

Tidak semua kegiatan perawatan rusunawa yang dilakukan oleh Pihak Disperkim sesuai dengan Peraturan Menteri Perumahan Rakyat No.14 Tahun 2007 Tentang Pengelolaan Rumah Susun Sederhana Sewa . Kegiatan yang dilakukan oleh Disperkim hanya kegiatan perawatan mendesak dan kegiatan perawatan darurat karena kegiatan tersebut dilakukan apabila terjadi kerusakan saja dan dibutuhkan tindakan perbaikan secepatnya. Dapat dilihat dari beberapa perbaikan fasilitas rusunawa di Kota Semarang yaitu penggantian pagar di rusunawa yang membahayakan penghuni seperti Rusunawa Kaligawe. Selain itu, perbaikan atap yang rusak di Rusunawa Plamongansari juga sudah dilakukan. Perbaikan ini dilakukan karena atap Rusunawa
Plamongansari yang bocor dan apabila turun hujan, maka rembesan air akan masuk ke dalam unit rusunawa.

4. Analisis Kegiatan Monitoring dan Evaluasi (Tahap Controlling) oleh Disperkim

Tujuan dilakukannya monitoring dan evaluasi adalah untuk menilai tahap pelaksanaan dan melakukan perbaikan-perbaikan sesuai dengan yang direncanakan sebelumnya (Terry, 2006). Monitoring dan evaluasi pada pengelolaan rusunawa Kota Semarang bertujuan agar prosedur pengelolaan dapat dinilai sehingga berjalan sesuai dengan yang seharusnya. Berdasarkan data Tabel 3, dapat dilihat bahwa pihak Disperkim melakukan monitoring hanya pada saat dilaksanakannya pemeliharaan dan perbaikan rusunawa (71\%), sehingga masih kurang intensif dalam melakukan monitoring. Tidak adanya agenda khusus untuk melaksanakan kegiatan monitoring. Dengan tidak intensifnya kegiatan monitoring dan evaluasi yang dilakukan oleh pihak Disperkim ini berdampak pada kondisi bangunan dan PSU rusunawa yang kurang baik.

Tabel 3. Kegiatan Monitoring dan Evaluasi oleh Pihak Disperkim

\begin{tabular}{|c|c|c|c|c|}
\hline $\begin{array}{c}\text { Kegiatan } \\
\text { Monitoring } \\
\text { dan Evaluasi } \\
\text { oleh Pihak } \\
\text { Disperkim }\end{array}$ & $\begin{array}{c}\text { Selalu } \\
\text { melakukan } \\
\text { monitoring } \\
\text { dan } \\
\text { evaluasi }\end{array}$ & $\begin{array}{c}\text { Monitoring } \\
\text { dilakukan hanya } \\
\text { pada saat } \\
\text { dilaksanakannya } \\
\text { pemeliharaan } \\
\text { dan perbaikan }\end{array}$ & $\begin{array}{c}\text { Jarang } \\
\text { melakukan } \\
\text { monitoring }\end{array}$ & $\begin{array}{c}\text { Tidak } \\
\text { pernah } \\
\text { melakukan } \\
\text { monitoring }\end{array}$ \\
\hline $\begin{array}{l}\text { Rusunawa } \\
\text { Pekunden }\end{array}$ & 1 & 0 & 0 & 0 \\
\hline $\begin{array}{l}\text { Rusunawa } \\
\text { Bandarharjo }\end{array}$ & 0 & 3 & 0 & 0 \\
\hline $\begin{array}{l}\text { Rusunawa } \\
\text { Plamongansari }\end{array}$ & 1 & 4 & 1 & 0 \\
\hline $\begin{array}{l}\text { Rusunawa } \\
\text { Karangroto }\end{array}$ & 1 & 2 & 0 & 0 \\
\hline $\begin{array}{l}\text { Rusunawa } \\
\text { Kaligawe }\end{array}$ & 0 & 7 & 0 & 0 \\
\hline $\begin{array}{l}\text { Rusunawa } \\
\text { Kudu }\end{array}$ & 1 & 4 & 2 & 0 \\
\hline $\begin{array}{l}\text { Rusunawa } \\
\text { Jrakah }\end{array}$ & 1 & 0 & 0 & 0 \\
\hline Jumlah & 5 & 20 & 3 & 0 \\
\hline Persentase & $18 \%$ & $71 \%$ & $11 \%$ & $0 \%$ \\
\hline
\end{tabular}

\section{B. Analisis Peran dan Fungsi UPTD Rusunawa Kota Semarang}

\section{Analisis Persyaratan Calon Penghuni Rusunawa} oleh Pihak UPTD Rusunawa

Sesuai dengan Peraturan Walikota Semarang no 7 Tahun 2009 tentang Penghunian dan Persewaan atas Rumah Sewa Milik Pemerintah Kota Semarang 
sasaran penghuni rusunawa Kota Semarang adalah masyarakat yang tergolong MBR dan belum memiliki rumah atau hunian yang layak. Dengan target sasaran penghuni tersebut, maka pihak pemerintah membuat persyaratan bagi calon penghuni rusunawa untuk bisa mendapatkan hak sewa rusunawa. Persyaratan-persyaratan tersebut harus dipenuhi agar bisa mendapat hunian rusunawa.

Sesuai dengan hasil kuesioner, prosedur pendaftaran calon penghuni sudah dilakukan dengan baik dibeberapa rusunawa yaitu Rusunawa Karangroto, Rusunawa Kaligawe, Rusunawa Kudu, Rusunawa Jrakah dan Rusunawa Bandarharjo (93\%). Adapun prosedurnya yaitu, persyaratan administrasi harus dilengkapi, serta penyeleksian berkas dan calon penghuni sesuai dengan kebutuhan hunian oleh pihak UPTD. Namun, di beberapa rusunawa tidak diberlakukan prosedur tersebut dikarenakan tujuan awal pembangunannya bukan untuk MBR. Tabel 4 merupakan tabel pemenuhan persyaratan administrasi calon penghuni Rusunawa di Kota Semarang.

Tabel 4. Pelaksanaan Prosedur Pendaftaran Calon Penghuni Rusunawa

\begin{tabular}{|l|c|c|c|c|}
\hline $\begin{array}{c}\text { Pelaksanaan Prosedur } \\
\text { Pendaftaran Calon } \\
\text { Penghuni Rusunawa }\end{array}$ & $\begin{array}{c}\frac{\text { Persyaratan }}{\text { administrasi }} \\
\text { harus lengkap }\end{array}$ & $\begin{array}{c}\frac{\text { Persyaratan }}{\text { administrasi }} \\
\frac{\text { kurang }}{\text { lengkap }}\end{array}$ & $\begin{array}{c}\text { Persyaratan } \\
\text { administrasi } \\
\text { tidak lengkap }\end{array}$ & $\begin{array}{c}\frac{\text { Tidak }}{\text { diberlakukan }} \\
\text { persyaratan } \\
\text { administrasi }\end{array}$ \\
\hline Rusunawa Pekunden & 0 & 0 & 0 & 1 \\
\hline RusunawaBandarharjo & 3 & 0 & 0 & 0 \\
\hline $\begin{array}{l}\text { Rusunawa } \\
\text { Plamongansari }\end{array}$ & 5 & 0 & 0 & 1 \\
\hline $\begin{array}{l}\text { Rusunawa } \\
\text { Karangroto }\end{array}$ & 3 & 0 & 0 & 0 \\
\hline Rusunawa Kaligawe & 7 & 0 & 0 & 0 \\
\hline Rusunawa Kudu & 7 & 0 & 0 & 0 \\
\hline Rusunawa Jrakah & 1 & 0 & 0 & 0 \\
\hline Jumlah & 26 & 0 & 0 & 2 \\
\hline Persentase & $\mathbf{9 3}$ & $\mathbf{0 \%}$ & $\mathbf{0 \%}$ & $\mathbf{7 \%}$ \\
\hline
\end{tabular}

Dari data Tabel 4, diketahui bahwa pada umumnya penetapan calon penghuni rusunawa sudah dilakukan sesuai dengan prosedur di semua rusunawa Kota Semarang. Dengan sudah diberlakukannya prosedur tersebut, maka seharusnya penghuni rusunawa di Kota Semarang sudah tepat sasaran. Namun pada kenyataannya, masih terdapat penghuni rusunawa yang dikategorikan sebagai masyarakat mampu, seperti di Rusunawa Pekunden dan Rusunawa Plamongansari. Dengan tidak diberlakukan persyaratan administrasi dan penyeleksian berkas terhadap calon penghuni di beberapa rusunawa tersebut, berdampak pada ketidaktepatan sasaran penghuni rusunawa di Kota Semarang. Dengan demikian, pihak UPTD harus lebih ketat dalam melaksanakan prosedur penetapan calon penghuni di rusunawa Kota Semarang agar sasaran penghuni khususnya MBR dan masyarakat yang belum memiliki hunian dapat tercapai.

\section{Analisis Sistem Sewa Menyewa Penghuni Rusunawa oleh Pihak UPTD Rusunawa}

Sesuai dengan Peraturan Walikota Semarang no 7 Tahun 2009 tentang Penghunian dan Persewaan atas Rumah Sewa Milik Pemerintah Kota Semarang bahwa perjanjian sewa menyewa penghuni berlaku hanya 2 (dua) tahun dan dapat diperpanjang. Perpanjangan perjanjian sewa menyewa dapat dilakukan sebanyak 3 (tiga) kali. Berdasarkan hasil kuesioner, diketahui bahwa penghuni rusunawa banyak yang sudah menempati rusunawa lebih dari 6 tahun dan penghuni juga tidak mengetahui jka terdapat peraturan batas waktu berapa lama penghuni bisa menempati rusunawa (lihat Tabel 5).

Tabel 5. Lama Penghuni dapat Tinggal di Rusunawa

\begin{tabular}{|l|c|c|c|c|}
\hline $\begin{array}{c}\text { Lama Penghuni } \\
\text { dapat Tinggal di } \\
\text { Rusunawa }\end{array}$ & $\begin{array}{c}2 \\
\text { tahun }\end{array}$ & $\begin{array}{c}3 \\
\text { tahun }\end{array}$ & $\begin{array}{c}\text { Paling } \\
\text { lama 6 } \\
\text { tahun }\end{array}$ & $\begin{array}{c}\text { Lebih } \\
\text { dari 6 } \\
\text { tahun }\end{array}$ \\
\hline $\begin{array}{l}\text { Rusunawa } \\
\text { Pekunden }\end{array}$ & 0 & 0 & 0 & 1 \\
\hline $\begin{array}{l}\text { Rusunawa } \\
\text { Bandarharjo }\end{array}$ & 0 & 0 & 0 & 3 \\
\hline $\begin{array}{l}\text { Rusunawa } \\
\text { Plamongansari }\end{array}$ & 0 & 0 & 0 & 6 \\
\hline $\begin{array}{l}\text { Rusunawa } \\
\text { Karangroto }\end{array}$ & 0 & 0 & 0 & 3 \\
\hline Rusunawa Kaligawe & 3 & 0 & 0 & 4 \\
\hline Rusunawa Kudu & 2 & 0 & 0 & 5 \\
\hline Rusunawa Jrakah & 0 & 0 & 0 & 1 \\
\hline Jumlah & 5 & 0 & 0 & 23 \\
\hline Persentase & $\mathbf{1 7 \%}$ & $\mathbf{0 \%}$ & $\mathbf{0 \%}$ & $\mathbf{8 3 \%}$ \\
\hline
\end{tabular}

Dari hasil kuesioner yang diberikan kepada paguyuban (PPRS), diketahui bahwa sebanyak $83 \%$ penghuni sudah tinggal di rusunawa selama lebih dari 6 (enam) tahun. Pada umumnya penghuni yang sudah tinggal lama di rusunawa Kota Semarang adalah penghuni Rusunawa Pekunden, Rusunawa Bandarharjo dan Rusunawa Plamongansari yang usia rusunawa tersebut sudah cukup tua. Bahkan beberapa penghuni rusunawa tersebut menempati rusunawa sejak lahir hingga berkeluarga dan tetap tinggal di rusunawa tersebut. Hal ini menunjukkan bahwa peran pihak UPTD dalam mengentaskan kemiskinan masyarakat dengan memberikan batas sewa penghuni rusunawa selama 2 tahun belum berjalan dengan baik. Pemerintah memberikan batas 
lama hunian selama 2 tahun dan boleh diperpanjang dengan tujuan agar penghuni diberikan kesempatan untuk meningkatkan perekonomian di rusunawa tersebut. Apabila dianggap sudah mampu untuk mandiri, maka pihak UPTD akan melepas hak sewa penghuni dan akan diberikan kepada calon penghuni lain yang lebih membutuhkan.

Selain target batas lama hunian rusunawa, permasalahan lain yang terjadi adalah pengalihan hak sewa penghuni atau dengan kata lain penghuni menjual kembali hak sewanya kepada orang lain. Di beberapa unit rusunawa, terdapat penghuni yang menempati unit rusunawa tidak atas namanya sendiri. Hal ini dikarenakan penghuni sebelumnya menjual hak sewanya kepada penghuni yang saat ini sedang menempati unit. Selain karena kurangnya kesadaran penghuni untuk mengurus pergantian hak sewa, prosedur untuk pergantian hak sewa dirasa masih menyulitkan dan membutuhkan biaya tambahan. Adanya biaya tambahan ini mengakibatkan penghuni terbebani, sehingga enggan untuk mengurus pergantian hak sewanya.

\section{Analisis Peran dan Fungsi Paguyuban Pengelola Rusunawa Kota Semarang}

Peran paguyuban rusunawa adalah sebagai koordinator pengelolaan rusunawa dan penyalur aspirasi penghuni kepada pihak pengelola rusunawa (UPTD dan Disperkim). Setiap blok rusunawa di Kota Semarang pada umumnya memiliki ketua paguyuban dan struktur organisasi paguyuban.

1. Analisis Bentuk dan Struktur Organisasi Paguyuban Rusunawa Kota Semarang

Dalam pengorganisasian rusunawa, setiap rusunawa diwajibkan membentuk paguyuban. Paguyuban ini didalam undang-undang disebut sebagai PPRS (Perhimpunan Penghuni Rusunawa) yang berfungsi untuk mengatur dan mengurus rusunawa. Sesuai dengan Peraturan Pemerintah Republik Indonesia Nomor 4 Tahun 1988 Tentang Rumah Susun Pasal 54 ayat (1) berbunyi: "para penghuni dalam suatu lingkungan rusunawa baik untuk hunian maupun bukan hunian wajib membentuk perhimpunan penghuni untuk mengatur dan mengurus kepentingan bersama yang bersangkutan dengan pemilikan, penghunian, dan pengelolaannya". Oleh karena itu, pembentukan paguyuban rusunawa di Kota Semarang adalah wajib.

Paguyuban pengelola rusunawa di Kota Semarang dibentuk atas partisipasi penghuni untuk membentuk perhimpunan penghuni dalam mengelola masing-masing rusunawa yang ada di Kota Semarang. Paguyuban ini merupakan kelompok sosial yang bersifat kekeluargaan, sehingga paguyuban pengelola rusunawa di Kota Semarang ini tidak memiliki legalitas. Walaupun tidak legal dalam sistem pemerintahan Kota Semarang, namun keberadaan paguyuban diakui oleh pemerintah sangat penting. Peran dan fungsi paguyuban ini sangat membantu pemerintah dalam hal pengelolaan masing-masing rusunawa di Kota Semarang.

Kelompok paguyuban ini dibentuk oleh penghuni dengan melakukan musyawarah untuk menunjuk ketua paguyuban. Setelah ketua paguyuban terpilih maka akan dibentuk struktur organisasi paguyuban yang dibutuhkan. Seksi-seksi dalam organisasi paguyuban ini pada dasarnya dibentuk sesuai dengan kebutuhan dalam pengelolaan rusunawa. Sesuai dengan Peraturan Menteri Perumahan Rakyat No.14 Tahun 2007 Tentang Pengelolaan Rumah Susun Sederhana Sewa, struktur organisasi paguyuban seharusnya seperti pada Gambar 2.

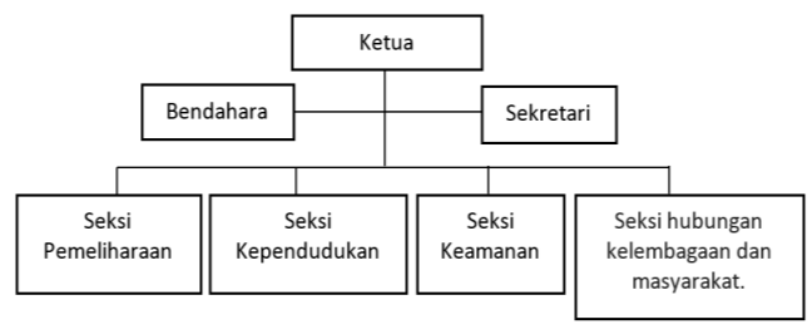

Gambar 2. Struktur Organisasi Paguyuban Pengelola dalam Permenpera No.14 Tahun 2007

Untuk struktur organisasi yang ada di masing-masing rusunawa di Kota Semarang berbeda-beda. Struktur organisasi paguyuban yang ada di masing-masing rusunawa disusun sesuai dengan kebutuhan dalam pelaksanaan pengelolanya. Untuk struktur organisasi yang sudah dibentuk di masing-masing rusunawa tidak ada yang sesuai dengan Peraturan Menteri Perumahan Rakyat No.14 Tahun 2007 Tentang Pengelolaan Rumah Susun Sederhana Sewa. Gambar 3 merupakan struktur organisasi paguyuban 
yang ada di masing-masing rusunawa Kota Semarang.

a. Rusunawa Pekunden

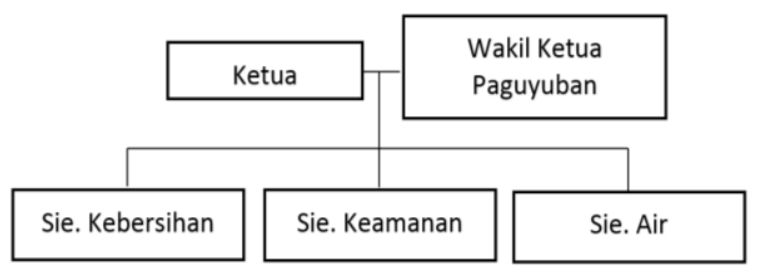

b. Rusunawa Bandarharjo

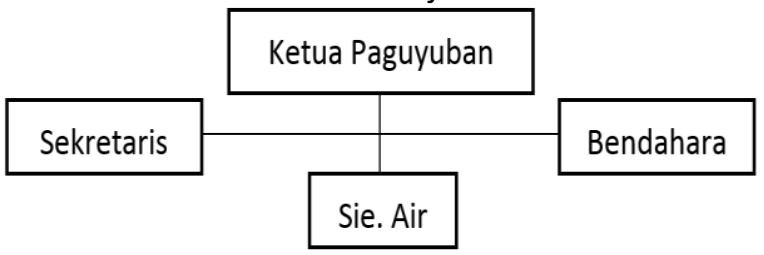

c. Rusunawa Karangroto

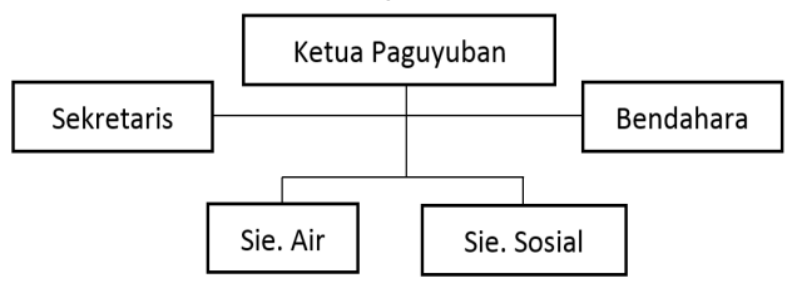

d. Rusunawa Kaligawe

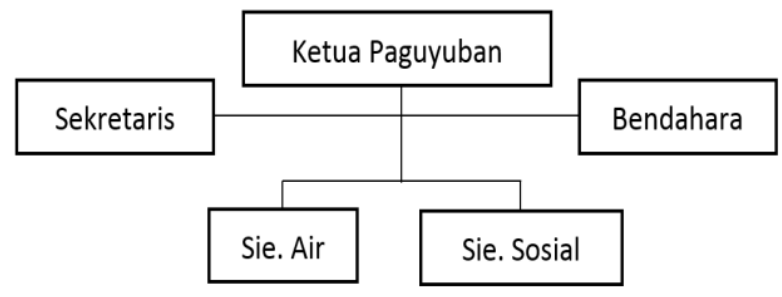

\section{e. Rusunawa Kudu}

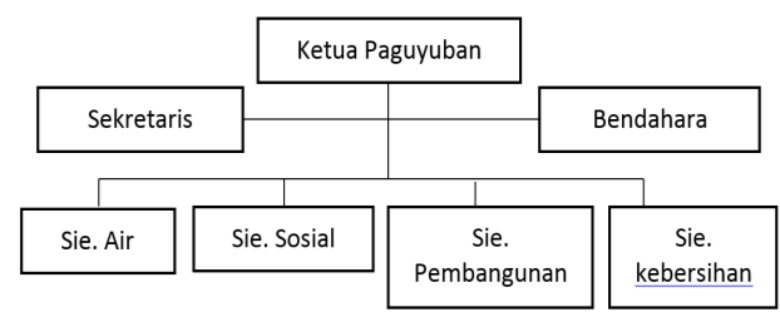

Gambar 3. Struktur Organisasi Paguyuban masing-masing Rusunawa Kota Semarang

Selain struktur organisasi, kegiatan yang dilakukan oleh masing-masing paguyuban seperti rapat rutin maupun pelaksanaan kegiatan pemeliharaan dijabarkan pada Tabel 6.
Tabel 6. Kegiatan Rutin Paguyuban

\begin{tabular}{|l|l|l|}
\hline \multicolumn{1}{|c|}{ Rusunawa } & \multicolumn{1}{|c|}{$\begin{array}{c}\text { Rapat } \\
\text { Rutin }\end{array}$} & \multicolumn{1}{|c|}{$\begin{array}{c}\text { Pelaksanaan } \\
\text { pemeliharaan } \\
\text { (gotong royong) }\end{array}$} \\
\hline $\begin{array}{l}\text { Rusunawa } \\
\text { Pekunden }\end{array}$ & $\begin{array}{l}1 \text { bulan } \\
\text { sekali }\end{array}$ & 1 minggu sekali \\
\hline $\begin{array}{l}\text { Rusunawa } \\
\text { Bandarharjo }\end{array}$ & $\begin{array}{l}\text { 2 bulan } \\
\text { sekali }\end{array}$ & 2 bulan sekali \\
\hline $\begin{array}{l}\text { Rusunawa } \\
\text { Plamongansari }\end{array}$ & $\begin{array}{l}1 \text { bulan } \\
\text { sekali }\end{array}$ & $\begin{array}{l}\text { Setiap minggu } \\
\text { (per RT) }\end{array}$ \\
\hline $\begin{array}{l}\text { Rusunawa } \\
\text { Kaligawe }\end{array}$ & $\begin{array}{l}2 \text { bulan } \\
\text { sekali }\end{array}$ & 1 bulan sekali \\
\hline $\begin{array}{l}\text { Rusunawa } \\
\text { Karangroto }\end{array}$ & $\begin{array}{l}1 \text { bulan } \\
\text { sekali }\end{array}$ & 1 bulan sekali \\
\hline Rusunawa Kudu & $\begin{array}{l}1 \text { bulan } \\
\text { sekali }\end{array}$ & 2 minggu sekali \\
\hline $\begin{array}{l}\text { Rusunawa } \\
\text { Jrakah }\end{array}$ & Tidak ada & Tidak ada \\
\hline
\end{tabular}

Berdasarkan data struktur organisasi paguyuban dan kegiatan paguyuban yang ada, dapat dinilai bahwa paguyuban yang memiliki organisasi paling baik di Kota Semarang adalah paguyuban Rusunawa Kudu khususnya Blok B. Dapat dilihat dari struktur organisasi yang cukup lengkap dan kegiatan rutin yang dilakukan sudah cukup baik. Selain itu, untuk penanganan permasalahan hunian di Rusunawa Kudu juga cukup baik, pihak paguyuban mampu mengelola penghuni dan mengelola fasilitas hunian yang ada dengan mengadakan rapat dan kegiatan gotong royong secara rutin.

Rusunawa Kota Semarang yang tidak memiliki paguyuban adalah Rusunawa Plamongansari. Pengelolaan rusunawa Plamongansari dilaksanakan oleh Ketua RT dan RW. Koordinasi antara penghuni kepada pihak pengelola rusunawa dilakukan oleh ketua RT masing-masing blok di Rusunawa Plamongansari, kemudian pihak RT akan menyampaikan kepada RW. Dari pihak RW akan langsung berkoordinasi kepada pihak Disperkim ataupun UPTD. Dalam kondisi tertentu, pihak RT dalam secara langsung berkordinasi kepada pihak Disperkim mauapun UPTD. Hal ini membuktikan bahwa, kewajiban untuk membentukan paguyuban rusunawa tidak dilaksanakan oleh penghuni rusunawa tersebut.

Adapaun kelebihan dari organisasi pengelolaan dalam bentuk RT adalah memudahkan koordinasi antara pihak pemerintah dengan pihak RT dikarenakan pihak RT merupakan struktur organisasi 
pemerintah terendah yang legal. Selain itu, menurut Yuliastuti dkk. (2017), RT juga merupakan lembaga terendah yang ada di masyarakat yang dapat dimanfaatkan untuk memelihara lingkungan secara berkelanjutan. Dalam hal ini, pihak RT juga mendapatkan dana operasional untuk pelaksanaan tugas mengelola rusunawa. Dengan dana operasional tersebut tentunya sangat membantu RT masing-masing dalam menjalankan peran dan fungsinya.

Selain kelebihan, adapun kelemahan yang terjadi dengan adanya organisasi pengelola rusunawa dalam bentuk RT adalah dengan banyaknya jumlah ketua RT yang berperan sebagai pengelola di rusunawa Plamongansari ini menyulitkan pihak UPTD/Disperkim dalam mengkolektifkan aspirasi penghuni. Masing-masing ketua RT akan menyampaikan asiprasi setiap penghuni kepada pihak UPTD/Disperkim. Adapun contoh bentuk aspirasi ini seperti pengajuan untuk perbaikan pada bangunan gedung rusunawa yang rusak atau meminta bantuan dalam penyediaan fasilitas rusunawa. Dengan banyaknya aspirasi terkait pengelolaan rusunawa tersebut akan sulit untuk dikolektifkan dengan baik oleh pihak UPTD/Disperkim. Begitu pula dalam hal pendataan penghuni, pihak UPTD juga akan kesulitan dalam melakukan pendataan karena koordinasi yang dilakukan kepada masing-masing Ketua RT. Semakin banyak Ketua RT, maka akan semakin menyulitkan dalam hal koordinasi terkait pendataan penghuni. Pendataan akan lebih mudah dilakukan apabila pihak UPTD berkoordinasi hanya kepada satu organisasi pengelola saja.

Pengelolaan Rusunawa Kota Semarang yang tidak memiliki paguyuban selain dilaksanakan oleh Ketua RT dan RW juga dilakukan oleh Pihak Keamanan. Rusunawa di Kota Semarang yang pengelolaannya dilakukan oleh pihak keamanan yang ditugaskan oleh pemerintah adalah Rusunawa Jrakah. Rusunawa Jrakah tidak memiliki struktur organisasi yang terlibat didalam pengelolaan rusunawa, seperti ketua, wakil ketua, sekretaris ataupun bendahara. Pengelolaan terkait penghunian dan kondisi fisik rusunawa diurus oleh petugas keamanan. Petugas keamanan tersebut adalah honorer yang diangkat oleh pihak Disperkim. Petugas keamanan ini hanya berfokus dalam menjaga keamanan penghuni, sehingga dinilai kurang mampu dalam menampung seluruh aspirasi penghuni. Jika terjadi permasalahan seperti masalah penghunian atau masalah kerusakan fasilitas gedung rusunawa, petugas keamanan akan menyampaikan permasalahan tersebut kepada pihak Disperkim atau UPTD.

Berdasarkan analisis bentuk dan struktur organisasi pengelola tersebut, dapat dirangkum dan disimpulkan bentuk organisasi yang dapat menjadi contoh pengelolan yang baik berdasarkan kelebihan dan kelemahan dari masing-masing bentuk organisasinya yang dapat dilihat pada Tabel 7.

Tabel 7. Perbandingan Kegiatan Pengelolaan oleh Pengelola

\begin{tabular}{|l|c|c|c|}
\hline \multicolumn{1}{|c|}{ Kegiatan } & Paguyuban & RT & $\begin{array}{c}\text { Pihak } \\
\text { Keamanan }\end{array}$ \\
\hline Rapat Rutin & Ada & Ada & Tidak Ada \\
\hline Gotong Royong & Ada & Ada & Tidak Ada \\
\hline $\begin{array}{l}\text { Struktur } \\
\text { Organisasi }\end{array}$ & Ada & Ada & Tidak Ada \\
\hline $\begin{array}{l}\text { Dana } \\
\text { Operasional }\end{array}$ & Tidak Ada & Ada & Ada \\
\hline $\begin{array}{l}\text { Koordinasi } \\
\text { dengan } \\
\text { pemerintah }\end{array}$ & Lambat & Cepat & Cepat \\
\hline $\begin{array}{l}\text { Inisiatif dalam } \\
\text { melaksanakan } \\
\text { pengelolaan }\end{array}$ & Kurang & Baik & Baik \\
\hline
\end{tabular}

Dari analisis pada Tabel 7, dapat dilihat bahwa bentuk organisasi pengelola rusunawa yang paling baik saat ini adalah RT karena telah memenuhi komponen penilaian yang ada, baik itu rapat rutin, gotong royong, struktur organisasi, dana operasional, koordinasi dengan pemerintah, inisiatif dalam melaksanakan pengelolaan. Dalam hal ini yang paling mendukung dalam pelaksanaan kegiatan pengelolaan adalah adanya dana operasional. Dengan adanya dana operasional, sangat membantu pihak pengelola dalam menjalankan tugasnya seperti pelaksanaan rapat, gotong royong hingga inisiatif pihak pengelola dalam melaksanakan tugasnya akan berpengaruh dengan adanya dana operasional yang diberikan oleh pemerintah.

2. Analisis Pemeliharaan dan Perawatan oleh Paguyuban Pengelola Rusunawa

Menurut Assauri (2008), proses pemeliharaan dapat dibedakan menjadi 2 (dua) jenis berdasarkan aktivitasnya, yaitu: 
1. Routine Maintenance : kegiatan pemeliharaan dan perawatan yang dilakukan dengan rutin, bahkan setiap hari.

2. Periodic Maintenance : kegiatan pemeliharaan dan perawatan yang dilakukan dalam jangka waktu tertentu atau secara periodic.

Dalam menjalankan peran dan fungsinya, paguyuban sebagai koordinator dalam pelaksanaan pengelolaan rusunawa Kota Semarang pada umumnya sudah berjalan dengan baik. Kegiatan rutin yang dilakukan berupa gotong royong. Tabel 8 merupakan data terkait pengadaan kegiatan rutin berdasarkan hasil kuesioner.

Tabel 8. Kegiatan Rutin Penghuni Untuk Merawat/Memperbaiki Kerusakan Fasilitas

Rusunawa

\begin{tabular}{|l|c|c|}
\hline $\begin{array}{l}\text { Kegiatan rutin penghuni untuk } \\
\text { merawat/memperbaiki kerusakan } \\
\text { fasilitas rusunawa }\end{array}$ & Ada & Tidak \\
\hline Rusunawa Pekunden & 1 & 0 \\
\hline Rusunawa Bandarharjo & 3 & 0 \\
\hline Rusunawa Plamongansari & 6 & 0 \\
\hline Rusunawa Karangroto & 3 & 0 \\
\hline Rusunawa Kaligawe & 7 & 0 \\
\hline Rusunawa Kudu & 7 & 0 \\
\hline Rusunawa Jrakah & 0 & 1 \\
\hline Jumlah & 27 & 1 \\
\hline Persentase & $\mathbf{9 6 \%}$ & $\mathbf{4 \%}$ \\
\hline
\end{tabular}

Dari hasil pada Tabel 8, 96\% penghuni di setiap rusunawa sudah melaksanakan kegiatan rutin berupa gotong royong dalam melakukan perawatan dan perbaikan fasilitas rusunawa sedangkan $4 \%$ yang belum melakukan adalah penghuni Rusunawa Jrakah. Hal ini dikarenakan kondisi Rusunawa Jrakah dihuni oleh para pekerja yang memiliki jadwal bekerja yang berbeda-beda sehingga sulit untuk menentukan jadwal gotong royong. Teknis pelaksanaan gotong royong disetiap rusunawa juga berbeda-beda.

\section{Analisis Pengelolaan Rusunawa Kota Semarang}

Berdasarkan analisis dari masing-masing pengelola rusunawa Kota Semarang di atas, dapat dilakukan penilaian terhadap komponen eksisting yang ada pada pengelolaannya. Berdasarkan yang telah dijelaskan pada metode penelitian, penelitian ini mengacu pada ambang batas skor Subkhan (2008) dengan mengklasifikasikan ke dalam 3 (tiga) penilaian, yaitu skor 8-10 (optimal), 5-7,9 (kurang optimal) dan 1-4,9 (tidak optimal) sesuai dengan penilaian terhadap komponen peran dan fungsi masing-masing pengelola di setiap rusunawa di Kota Semarang. Adapun komponen peran dan fungsi masing-masing pengelola yang dinilai yaitu (1) Disperkim terkait pemeliharaan dan perawatan rusunawa, Intensitas pemerintah memberikan bantuan untuk pemeliharaan rusunawa, pembinaan penghuni, monitoring dan evaluasi; (2) UPTD Rusunawa terkait tepat sasaran penghuni, pelaksanaan prosedur pendaftaran, pembagian unit, dan penempatan, sistem sewa menyewa, pembinaan penghuni, pengorganisasian, monitoring dan evaluasi; serta (3) Paguyuban terkait pengorganisasian, pemeliharaan dan perawatan rusunawa (lihat Tabel 9, 10, 11).

Tabel 9. Analisis Pengelolaan Rusunawa Kota Semarang oleh Disperkim

\begin{tabular}{|l|l|l|l|l|l|l|l|}
\hline \multicolumn{1}{|c|}{ Komponen } & RP & RB & RPI & RKar & Rkal & RKu & Rj \\
\hline $\begin{array}{l}\text { Pemeliharaan } \\
\text { dan perawatan } \\
\text { rusunawa }\end{array}$ & 7 & 7 & 7 & 7 & 7 & 7 & 10 \\
\hline $\begin{array}{l}\text { Intensitas } \\
\text { pemerintah } \\
\text { memberikan } \\
\text { bantuan untuk } \\
\text { pemeliharaan } \\
\text { rusunawa }\end{array}$ & 7 & 7 & 10 & 7 & 7 & 7 & 10 \\
\hline $\begin{array}{l}\text { Pembinaan } \\
\text { penghuni }\end{array}$ & 7 & 7 & 7 & 7 & 7 & 7 & 7 \\
\hline Monitoring & 7 & 7 & 7 & 7 & 7 & 7 & 10 \\
\hline Evaluasi & 7 & 7 & 7 & 7 & 7 & 7 & 10 \\
\hline Jumlah Skor & 35 & 35 & 38 & 35 & 35 & 35 & 47 \\
\hline Rata-Rata Skor & $\mathbf{7}$ & $\mathbf{7}$ & $\mathbf{7 , 6}$ & $\mathbf{7}$ & $\mathbf{7}$ & $\mathbf{7}$ & $\mathbf{9 , 4}$ \\
\hline Total Skor & $\mathbf{7 , 4}$ & \multicolumn{7}{|l|}{} & & 7 & & \\
\hline
\end{tabular}

Keterangan:

RP : Rusun Pekunden

RB : Rusunawa Bandarharjo

RPI : Rusunawa Plamongansari

Rkar: Rusunawa Karangroto

Rkal : Rusunawa Kaligawe

Rku : Rusunawa Kudu

Rj : Rusunawa Jrakah

Berdasarkan hasil perhitungan penilaian optimalisasi pengelolaan oleh Diperkim pada Tabel 9, diketahui bahwa pihak Disperkim mendapatkan skor 7,4 (kurang optimal). Pihak Disperkim masih belum optimal dalam melaksanakan pengelolaan rusunawa. Adapun peran dan fungsi Disperkim yaitu dalam hal pengelolaan fisik rusunawa seperti bangunan gedung dan PSU rusunawa. Dalam pelaksanaan pengelolaannya, kondisi fisik di beberapa rusunawa Kota Semarang masih buruk, seperti terjadinya kebocoran-kebocoran pada unit rusunawa, sanitasi yang buruk, drainase yang 
tersumbat, biaya listrik dan air yang mahal, tandon air yang rusak, pompa air yang rusak, dan sebagainya. Hal ini dikarenakan masih kurang optimalnya peran Disperkim dalam mengelola rusunawa. Padahal pihak Disperkim mengakui bahwa anggaran biaya yang diajukan untuk pengoperasionalan rusunawa sudah cukup dan selalu dianggarkan setiap tahunnya sesuai dengan kebutuhan. Selain itu, monitoring dan evaluasi juga masih harus ditingkatkan. Dengan dilaksanakannya kegiatan monitoring dan evaluasi secara rutin, pihak Disperkim akan lebih sigap dalam memantau kondisi fisik rusunawa tanpa harus menunggu laporan dari pihak penghuni jika terjadi kerusakan pada fasilitas rusunawa. Pembinaan serta pengawasan terhadap penghuni juga sebaiknya dilakukan secara rutin agar penghuni mengetahui lebih baik cara menjaga kondisi fisik rusunawa dan turut serta dalam pelaksanaan pengelolaan seperti pemeliharaan dan perawatan rusunawa.

Tabel 10. Analisis Pengelolaan Rusunawa Kota Semarang oleh UPTD Rusunawa

\begin{tabular}{|c|c|c|c|c|c|c|c|}
\hline Komponen & $\mathrm{RP}$ & RB & RPI & RKar & Rkal & RKu & $\mathrm{Rj}$ \\
\hline $\begin{array}{l}\text { Tepat sasaran } \\
\text { penghuni }\end{array}$ & 3 & 7 & 3 & 7 & 7 & 7 & 10 \\
\hline $\begin{array}{l}\text { Pelaksanaan } \\
\text { prosedur } \\
\text { pendaftaran, } \\
\text { pembagian } \\
\text { unit dan } \\
\text { penempatan } \\
\text { hunian }\end{array}$ & 7 & 10 & 7 & 10 & 10 & 10 & 10 \\
\hline $\begin{array}{l}\text { Sistem sewa } \\
\text { menyewa }\end{array}$ & 3 & 3 & 3 & 3 & 3 & 3 & 7 \\
\hline $\begin{array}{l}\text { Pembinaan } \\
\text { penghuni }\end{array}$ & 7 & 7 & 7 & 7 & 7 & 7 & 7 \\
\hline $\begin{array}{l}\text { Pengorganisa } \\
\text { sian }\end{array}$ & 7 & 7 & 7 & 7 & 7 & 7 & 7 \\
\hline $\begin{array}{l}\text { Ketersediaan } \\
\text { jumlah } \\
\text { tenaga dan } \\
\text { kemampuan } \\
\text { anggota } \\
\text { pengelola }\end{array}$ & 3 & 3 & 3 & 3 & 3 & 3 & 3 \\
\hline Monitoring & 7 & 7 & 7 & 7 & 7 & 7 & 10 \\
\hline Evaluasi & 7 & 7 & 7 & 7 & 7 & 7 & 10 \\
\hline Jumlah Skor & 44 & 51 & 44 & 51 & 51 & 51 & 64 \\
\hline $\begin{array}{l}\text { Rata-Rata } \\
\text { Skor }\end{array}$ & 5,5 & 6,4 & 5,5 & 6,4 & 6,4 & 6,4 & 8 \\
\hline Total Skor & 6,4 & & & & & & \\
\hline
\end{tabular}

\section{Keterangan:}

RP : Rusun Pekunden

RB : Rusunawa Bandarharjo

RPI : Rusunawa Plamongansari

Rkar: Rusunawa Karangroto

Rkal : Rusunawa Kaligawe

Rku : Rusunawa Kudu

$\mathrm{Rj} \quad$ : Rusunawa Jrakah
Berdasarkan hasil perhitungan penilaian optimalisasi pengelolaan oleh UPTD Rusunawa pada Tabel 10, diketahui bahwa pihak UPTD Rusunawa mendapatkan skor 6,4 (kurang optimal). Pihak UPTD juga masih belum optimal dalam menjalankan peran dan fungsinya dalam mengelola penghuni rusunawa. Dapat dilihat dari sasaran penghuni rusunawa yang tidak tepat. Dibeberapa rusunawa masih terdapat penghuni yang memiliki penghasilan diatas Rp2.500.000,- sehingga tidak sesuai dengan aturan yang ditetapkan oleh pemerintah bahwa penghasilan minimal penghuni yang boleh menempati rusunawa adalah $<R p 2.500 .000,-$. Selain itu, masalah seperti sistem sewa menyewa penghuni yang tejadi yaitu adanya pengalihan hak sewa penghuni kepada orang lain, sehingga saat ini masih terdapat beberapa penghuni yang tinggal dirusunawa tetapi tidak atas namanya sendiri. Perlunya pembinaan dan pengawasan yang rutin dari pihak UPTD agar penghuni lebih mengetahui proses penghunian selama tinggal di rusunawa. Hal ini juga dapat mengurangi pelanggaran-pelanggaran terhadap tata tertib penghuni seperti tidak terlambatnya lagi penghuni membayar biaya sewa, tidak terjadinya pengalihan hak sewa, maupun penghuni tidak lagi memelihara hewan peliharaan.

Tabel 11. Analisis Pengelolaan Rusunawa Kota Semarang oleh Paguyuban

\begin{tabular}{|l|l|l|l|l|l|l|l|}
\hline Komponen & RP & RB & RPI & RKar & Rkal & RKu & Rj \\
\hline $\begin{array}{l}\text { Pengorgan } \\
\text { isasian }\end{array}$ & 7 & 7 & 7 & 7 & 7 & 7 & 3 \\
\hline $\begin{array}{l}\text { Pemelihar } \\
\text { aan dan } \\
\text { perawatan } \\
\text { rusunawa }\end{array}$ & 10 & 10 & 10 & 10 & 10 & 10 & 3 \\
\hline $\begin{array}{l}\text { Jumlah } \\
\text { Skor }\end{array}$ & 17 & 17 & 17 & 17 & 17 & 17 & 6 \\
\hline $\begin{array}{l}\text { Rata-Rata } \\
\text { Skor }\end{array}$ & $\mathbf{8 , 5}$ & $\mathbf{8 , 5}$ & $\mathbf{8 , 5}$ & $\mathbf{8 , 5}$ & $\mathbf{8 , 5}$ & $\mathbf{8 , 5}$ & $\mathbf{3}$ \\
\hline Total Skor & \multicolumn{7}{|c|}{$\mathbf{7 , 7}$} \\
\hline
\end{tabular}

Keterangan:

RP : Rusun Pekunden

RB : Rusunawa Bandarharjo

RPI : Rusunawa Plamongansari

Rkar: Rusunawa Karangroto

Rkal : Rusunawa Kaligawe

Rku : Rusunawa Kudu

Rj : Rusunawa Jrakah

Berdasarkan hasil perhitungan penilaian optimalisasi pengelolaan oleh Paguyuban pada Tabel 11, diketahui bahwa pihak Paguyuban mendapatkan skor 7,7 (kurang optimal). Dalam pelaksanaan pengelolaan, pihak paguyuban sudah melakukan perannya dalam kegiatan pemeliharaan dan 
perawatan rusunawa, namun tidak semua rusunawa memiliki paguyuban dan struktur organisasi yang ada didalam paguyuban masih belum lengkap seperti hanya ada ketua dan bendahara saja. Sebaiknya disetiap rusunawa memiliki ketua paguyuban dan struktur organisasi yang lengkap seperti diadakannya sie. sosial, sie. kebersihan, sie. keuangan, dan seksi-seksi lain yang dibutuhkan oleh penghuni dalam pengoperasionalan rusunawa. Selain itu, yang menjadi kelemahan adalah setiap blok rusunawa pada umumnya memiliki ketua paguyuban, atau dalam arti dalam satu rusunawa, memiliki banyak ketua paguyuban. Dalam hal ini menyulitkan pemerintah dalam melakukan koordinasi kepada pihak penghuni, begitu pula sebaliknya. Sebaiknya setiap rusunawa memiliki ketua paguyuban yang mengurus satu kesatuan rusunawa, agar koordinasi antarpihak dapat dilakukan dengan baik.

Berdasarkan Tabel 9, 10, 11, diketahui bahwa pengelolaan rusunawa yang dilakukan oleh pihak pengelola rusunawa pada umumnya masih belum optimal. Adapun skor yang diperoleh dari masingmasing pengelola bedasarkan urutannya yaitu: pihak Paguyuban dengan skor 7,7 (kurang optimal), pihak Disperkim dengan skor 7,4 (kurang optimal), dan pihak UPTD dengan skor 6,4 (kurang optimal). Dari ketiga skor yang diperoleh berdasarkan penilaian terhadap pengelolaan yang dilakukan oleh pengelola tersebut, maka rata-rata skor yang diperoleh secara keseluruhan adalah 7,2 yang tergolong kedalam kurang optimal.

Berdasarkan hasil skor penilaian optimalisasi pengelolaan rusunawa diketahui bahwa pihak Paguyuban memiliki nilai skor yang lebih tinggi dibanding yang lainnya, hal tersebut salah satunya dikarenakan pihak Paguyuban merupakan pengelola yang secara langsung dalam sehari-hari terlibat di lapangan terkait pengelolaan terhadap penghuni maupun hunian. Sedangkan pihak Disperkim dan UPTD rusunawa merupakan pengelola yang melaksakan pemeliharaan perbaikan secara corrective maintenance yaitu hanya dilakukan apabila terjadi kerusakan pada fasilitas hunian rusunawa dan tidak secara langsung berkomunikasi dengan penghuni terkait kondisi hunian di rusunawa. Hal inilah salah satu faktor yang mempengaruhi skor optimalisasi pihak Paguyuban lebih tinggi dibanding pengelola yang lainnya.
Secara umum, pengelolaan rusunawa Kota Semarang yang dilakukan masih kurang optimal. Hal ini diakibatkan karena masing-masing pengelola rusunawa masih belum optimal dalam menjalankan peran dan fungsinya baik mengelola proses penghunian maupun mengelola fisik bangunan dan PSU rusunawa. Dalam pelaksanaan peran dan fungsinya, pihak UPTD adalah pihak yang paling banyak berperan dalam pengelolaan rusunawa Kota Semarang karena berurusan dengan bagian pengelolaan penghunian rusunawa, sedangkan pihak Disperkim berurusan dengan pengelolaan fisik rusunawa serta pihak paguyuban sebagai koordinator pengelola di masing-masing rusunawa Kota Semarang. Kurang optimalnya pengelolaan rusunawa Kota Semarang ini dapat dilihat dari permasalahan seperti kondisi fisik bangunan dan PSU yang rusak dan belum diperbaiki, kegiatan pemeliharaan yang kurang rutin, penghuni yang melanggar tata tertib seperti terlambat membayar sewa dan adanya pengalihan hak sewa penghuni kepada orang lain.

\section{KESIMPULAN}

Pengelolaan rusunawa yang ada di Kota Semarang yang dilakukan oleh pengelola masih belum optimal. Adapun pengelola rusunawa Kota Semarang adalah Disperkim, UPTD dan Paguyuban pengelola masingmasing rusunawa Kota Semarang. Faktor penyebab belum optimalnya pengelolaan rusunawa Kota Semarang berdasarkan peran dan fungsi masingmasing pengelola rusunawa dengan komponen seperti pemeliharaan dan perbaikan, pembinaan, monitoring, evaluasi, struktur organisasi, prosedur penghunian, tepat sasaran penghuni, sistem sewa menyewa maupun karakteristik fisik rusunawa dan karakteristik sosial ekonomi penghuni.

Untuk pengelolaan di masing-masing rusunawa, peran pihak pemerintah (Disperkim dan UPTD) dan paguyuban masih kurang optimal. Hal ini dapat dilihat dari jumlah skor yang diperoleh yaitu pihak Paguyuban dengan skor $(7,7)$, pihak Disperkim dengan skor $(7,4)$, dan pihak UPTD Rusunawa dengan skor $(6,4)$. Oleh karena itu, perlu dilakukan pengoptimalan pengelolaan rusunawa sesuai dengan peran dan fungsi masing-masing pengelola seperti: (1) pemeliharaan dan perbaikan fasilitas rusunawa; monitoring dan evaluasi target capaian 
pengelolaan; serta pembinaan dan pengawasan terkait kebersihan lingkungan terhadap penghuni secara rutin oleh Disperkim; (2) pembinaan terhadap penghuni dan hunian; serta melakukan prosedur pengelolaan dan monitoring secara ketat oleh UPTD Rusunawa untuk mengurangi pelanggaran terhadap tata tertib penghuni, seperti keterlambatan dalam membayar biaya sewa, tidak terjadinya pengalihan hak sewa maupun penghuni tidak lagi memelihara hewan peliharaan; (3) Melakukan pengorganisasian paguyuban dengan membentuk paguyuban dan struktur organisasi lengkap seperti sie. sosial, sie. kebersihan, sie. keuangan, sie pemeliharaan dan seksi-seksi lainnya yang dibutuhkan dalam pengoperasionalan rusunawa agar memudahkan koordinasi antarpihak untuk mengatasi permasalahan penghuni dan meningkatkan kualitas hunian rusunawa.

\section{DAFTAR PUSTAKA}

Ardiyanti, F., \& Rahaju, T. (2019). Evaluasi Pengelolaan Rumah Susun Sederhana Sewa (Rusunawa) Ngelom Kecamatan Taman Kabupaten Sidoarjo. Publika, 7(7). Doi: https://doi.org/10.26740/publika.v7n7.p\%2 $5 p$

Assauri, S. (2008). Manajemen Produksi dan Operasi edisi revisi. Jakarta: Lembaga Penerbit Fakultas Ekonomi Universitas Indonesia.

Astuti, W. D. (2021). Optimalisasi Fasilitas dan Pengelolaan Rusunawa di Kota Magelang (Studi Kasus Rusunawa Potrobangsan Kota Magelang). Jurnal Paradigma Multidisipliner (JPM), 2(1), 55-65. Doi: https://doi.org/ $10.1210 / . v 2 \mathrm{i} 1.64$

Hendaryono, S. M. (2010). Evaluasi Pengelolaan Rusun Pekunden dan Bandarharjo Semarang. (Doctoral), Universitas Diponegoro.

O'Connor, P. D. T. (2001). Practical Realibility Engineering, Fourth Edition. England: John Wiley \& Sons. Ltd.

Peraturan Menteri Perumahan Rakyat No.14 Tahun 2007 Tentang Pengelolaan Rumah Susun Sederhana Sewa.

Peraturan Pemerintah Republik Indonesia Nomor 4 Tahun 1988 Tentang Rumah Susun.

Peraturan Walikota Semarang no 7 Tahun 2009 tentang Penghunian dan Persewaan atas
Rumah Sewa Milik Pemerintah Kota Semarang.

Permatasari, G. A. A. (2012). Backlog Perumahan dan Strategi Pemerintah dalam Pengadaan Perumahan Bagi Masyarakat Berpenghasilan Rendah (Studi Kasus: Jakarta Timur). Universitas Indonesia.

Purnamasari, A. W., Soemitro, R. A., \& Suprayitno, H. (2020). Perbandingan Pengelolaan Rusunawa: Pemilik, Penghuni, Pengelola, Pembiayaan, Luas Unit, Tarif dan Fasilitas. Jurnal Manajemen Aset Infrastruktur \& Fasilitas, 4(2), 167-182. Doi: http:// dx.doi.org/10.12962/j26151847.v4i2.6889

Sari, M. M., Haryani, H., \& Aditia, E. (2016). Strategi Optimalisasi Pengelolaan Rumah Susun Sederhana Sewa Kota Padang. Abstract of Undergraduate Research, Faculty of Civil and Planning Engineering, Bung Hatta University, 1(3).

Sitepu, A. (2006). Organisasi Sosial Lokal: Profil, Peran dan Rekomendasi untuk Pembangunan Kesejahteraan Sosial. Sosio Konsepsia: Jurnal Penelitian dan Pengembangan Kesejahteraan Sosial, 11(2), 11-23. Doi: https://doi.org/10.33007/ska. v11i2.593

Soukotta, J., Sompie, B. F., \& Timboeleng, J. A. (2013). Evaluasi Faktor-Faktor yang Mempengaruhi Pengelolaan Rusunawa (Studi Kasus: Rusunawa Wangurer, Tangkoko dan Unsrat). Jurnal IImiah Media Engineering, 3(1), 35-41.

South Hampshire Housing Market Assessment. (2005). Housing Need Backlog: Overview (pp. 88-96).

Subkhan, M. (2008). Pengelolaan Rumah Susun Sederhana Sewa di Cengkareng Jakarta Barat. (Doctoral), Program Pascasarjana Universitas Diponegoro.

Sugiyono. (2017). Metode Penelitian Pendidikan: Pendekatan Kuantitatif, Kualitatif, R\&D. Bandung: CV Alfabeta.

Terry, G. R. (2006). Principles of Management. Bandung: Alumni.

Ugochukwu, I. B., \& Chioma, M. I. B. (2015). Local Building Materials: Affordable Strategy for Housing the Urban Poor in Nigeria. Procedia Engineering, 118, 42-49. Doi: https:// doi.org/10.1016/j.proeng.2015.08.402 
Vásquez, S. D., Alpuche, G., Marincic, I., \& Ochoa, M. (2014). Energy Saving in a Dry Climate and Vertical Housing. Energy Procedia, 57, 16871695. Doi: https://doi.org/10.1016/j.egypro. 2014.10.159

Yuliastuti, N., Wahyono, H., Syafrudin, S., \& Sariffuddin, S. (2017). Dimensions of Community and Local Institutions' Support: Towards an Eco-Village Kelurahan in Indonesia. Sustainability, 9(2), 245. Doi: https://doi.org/10.3390/su9020245 